\title{
The bankruptcy law of Saudi Arabia: policy, operation and comparison
}

\author{
Fahad Alarifi \\ Aramco, Dhahran, Saudi Arabia
}

\begin{abstract}
Purpose - The purpose of the paper is to analyze the new Bankruptcy Law in Saudi Arabia (KSA Bankruptcy Law) under both a comparative lens and a policy-oriented one, while highlighting some of the most essential operational steps and procedures in a bankruptcy proceeding under the law.

Design/methodology/approach - The approach adopted analyzes the specific mechanics and procedures of a bankruptcy law under the general policies and goals of bankruptcy. Additionally, where appropriate, a brief comparison to the US Bankruptcy code and its provisions is presented to provide an alternative approach on how similar issues are handled under a reputable and proven bankruptcy system.

Findings - Overall, the KSA Bankruptcy Law is a major accomplishment and advancement to the Kingdom's insolvency regime. The law consolidated and codified the laws governing bankruptcy under the Kingdom's prior regime, and followed the structure of a modern bankruptcy regime. In doing so, several of the law's policies and objectives have been fulfilled by providing an effective, predictable and reliable bankruptcy system.

Originality/value - Given the relatively recent adoption of the KSA Bankruptcy Law, the paper provides a comprehensive assessment of the law's operation and its effectiveness in achieving its policy goals as a modern bankruptcy law.
\end{abstract}

Keywords Law, Bankruptcy law, Insolvency law

Paper type Research paper

The first part of this paper provides a discussion on the general policies of a modern bankruptcy system, which is used as the basis for analyzing the operational aspects of the KSA Bankruptcy Law and their underlying policies. This is followed by an overview of the structure of the law, as well as a discussion of the express policy goals stated in the law. Then, a discussion is provided of preliminary matters regarding jurisdiction, oversight and standing in bankruptcy cases under the KSA Bankruptcy Law. Following that, the paper provides an operational, comparative and policy-based analysis of certain bankruptcy procedures under the law and the specific bankruptcy features present under such procedures. The choice of which provisions and procedures are highlighted in the analysis is based on those most relevant from the perspective of a bankruptcy lawyer representing the debtor or the creditor in a proceeding, as well as those that address certain bankruptcy features that are essential to an effective bankruptcy regime.

(C) Fahad Alarifi. Published in PSU Research Review. Published by Emerald Publishing Limited. This article is published under the Creative Commons Attribution (CC BY 4.0) licence. Anyone may reproduce, distribute, translate and create derivative works of this article (for both commercial and non-commercial purposes), subject to full attribution to the original publication and authors. The full terms of this licence maybe seen at http://creativecommons.org/licences/by/4.0/legalcode Received 8 February 2021
Revised 18 April 2021
22 April 2021
Accepted 30 April 2021 law of Saudi

Arabia 
Historically, bankruptcy has been a creditor process and for the benefit of creditors by providing a collective procedure to liquidate the debtor's assets and share the proceeds. However, modern bankruptcy systems have expanded the beneficiary base of bankruptcy protections to include other stakeholders by providing for restructuring procedures that allow bankrupt businesses to continue their operations and survive bankruptcy for the benefit of a larger constituency (Tabb, 1995).

The presence of a modern effective insolvency system offers the possibility to restructure debts and reorganize businesses, allowing debtors the opportunity to fix any current or impending financial problems and save the business. Saving a distressed or bankrupt business serves many policies and benefits multiple parties and stakeholders beyond the debtor; maximizes payment to creditors who would otherwise be limited to the discounted liquidation value of the assets of the distressed business; guarantees equality among the creditors, it preserves jobs for the employees; preserves business relations to dependent vendors and suppliers; and preserves the tax base for the community, as well as other economic and social benefits (Warren, 1987, p. 788). Furthermore, the existence of an effective and predictable bankruptcy system incentivizes both entrepreneurship and investment in businesses as debtors can rely and use the system, which, as a result, leads to general economic growth and attracting foreign investment (International Monetary Fund, 1999, pp. 5-12).

A well-designed bankruptcy system should also incentivize debtors to seek early protection of the system to save their businesses before they become balance-sheet insolvent or before it becomes too late to restructure and continue a profitable business (International Monetary Fund, 1999, p. 18).

A fundamental goal of modern bankruptcy systems is the dischargeability of debt and the fresh-start concept, which provides debtors and businesses the opportunity to continue contributing to the economy unhindered by past failures and overhanging liabilities by relieving the honest debtor from the weight of indebtedness, which results in an environment and incentive for entrepreneurship and business risk taking. While liquidated entities cease to exist and by default are discharged, individual debtors continue to exist and, without a discharge of past pre-bankruptcy liabilities, they will be hindered by such liabilities from contributing to the economy (Jackson, 1985).

Another fundamental goal in bankruptcy is the equitable distribution of assets between creditors and debtors, and among creditors (Warren, 1987, pp. 789-793). Bankruptcy essentially alters existing contractual rights of parties to achieve an equitable outcome for the benefit of all. Therefore, a successful bankruptcy law should be designed in a manner that provides an incentive for all parties to negotiate and reach an agreement to restructure the debts and continue the business (Brown, 1989). This is achieved for example in the US chapter 11 bankruptcy restructuring through the laws striking a balance between the rights and protections of all the parties involved which has the effect of promoting reasonable negotiations to reach an agreement and adopt a restructuring plan (Boude, 1984).

As for creditors, the bankruptcy system provides a collective and equitable process that protects creditors from each other as well as from the debtor. The joint collective feature of the system protects creditors from fellow creditors reaching the debtor's assets before others, thus, providing an equal sharing opportunity. However, the availability of voidance of fraudulent transfers and the risks of penal liability to concealment of assets or fraud by the debtor protects the creditors from the debtor (Baird, 1983). 


\section{An overview of the KSA bankruptcy law}

Section 2.1 provides an introductory discussion on the adoption of the new bankruptcy law in Saudi Arabia and its precedent. Section 2.2 explores the policy goals and aims stated in the law. Finally, Section 2.3 explains the structure and organization of the new law.

\subsection{Adoption of the law}

Saudi Arabia adopted the current bankruptcy law (KSA Bankruptcy Law) in 2018, pursuant to Royal Decree Number M/50 dated 28/05/1439H. The law replaced the old insolvency regime in the Kingdom, which was based on Articles 103-137 of the Commercial Court Law issued by Royal Decree No. 32, dated 15/1/1350H; and the Bankruptcy Protective Settlement Law issued by Royal Decree No. M/16, dated 4/9/1416H (Bankruptcy Law 2018 (KSA), art. 230).

In addition, Saudi Arabia adopted the Implementing Regulations for the bankruptcy law pursuant to the Council of Ministers resolution Number 622 dated 24/12/1439H. In several articles of the KSA Bankruptcy Law, the provisions explicitly refer to the Implementing Regulations to determine and specify additional details and provisions for applying the law [Bankruptcy Law Implementing Regulations 2018 (KSA), art. 1].

These modernizations of the Kingdom's bankruptcy laws and alignment with established bankruptcy regimes are in accordance with the Kingdom's 2030 vision that aims to diversify the economy and achieve economic growth through a thriving local business environment and attracting foreign investment (George, 2018). Therefore, an overarching goal for this regime is to have a business-friendly bankruptcy code that will benefit the economy and attract investment. However, the fact that the law remains relatively new and the Kingdom's limited experience with a modern bankruptcy regime should be highlighted when assessing the law's effectiveness at achieving its goals.

\subsection{Policies and goals of the KSA bankruptcy law}

Article 5 of the KSA Bankruptcy Law expressly states the specific goals the bankruptcy procedures aim to achieve [Bankruptcy Law 2018 (KSA), art. 5].

One such goal is to enable a debtor in financial strain to benefit from the law's protections to restructure its financial position and maintain its activities to contribute to the economy and support it. This provision illustrates two interrelated bankruptcy policy goals, that of saving the debtor, and contributing to economy. The availability of restructuring mechanisms and allowing debtors early access to the system even before they become balance-sheet insolvent reflect this important aspect of the system.

The second expressed goal is to consider the creditor's rights and to ensure a fair treatment among creditors. This policy highlights the important and prominent bankruptcy principle to achieve equality among the creditors and protect them from fellow creditors overreaching. This policy is achieved through having a single collective process for all creditors to participate in equally preventing a race to the debtor's assets among creditors and ensuring an equitable distribution by treating equally ranked creditors similarly.

Another goal is to maximize the value of the assets, ensure a controlled sale of the assets and a fair distribution of the sale proceeds upon liquidation. Bankruptcy provides the opportunity to sell a distressed business as a going concern, which in almost all cases will have a higher value than the combined value of all the assets in a liquidation, therefore, maximizing the benefit to creditors upon distribution. Furthermore, the bankruptcy system and procedures provide for a fair (which does not necessarily mean equal) distribution among the creditors, which takes into consideration many factors to determine a fair distribution, such as security interests, ranking and timing. 
In addition, the bankruptcy procedure provides for more efficiency and procedural cost saving through a single collective process for the benefit of all creditors. The final expressed policy aim under Article 5 is to undertake an administrative liquidation when a debtor's assets are not expected to cover the costs of a Liquidation Procedure.

\subsection{Structure and organization of the KSA bankruptcy law}

The KSA Bankruptcy Law consists of 231 Articles in total, categorized within 17 Chapters. In general, the law provides for four main bankruptcy procedures that can be used, and three additional sub-procedures for small debtors. The main procedures available are Protective Settlement, Financial Restructuring, Liquidation and Administrative Liquidation procedures. The additional procedures for small debtors are Small Debtors Protective Settlement, Small Debtors Financial Restructuring and Small Debtors Liquidation procedures.

The Protective Settlement Procedure as defined in Article 1 is a procedure aiming to facilitate reaching an agreement between the debtor and its creditors to settle its debts, where the debtor maintains the right to manage its activities [Bankruptcy Law 2018 (KSA), art. 1]. The details and procedures for the Protective Settlement Procedure are covered under chapter 3 of the KSA Bankruptcy Law, from Article 13 to Article 41. In the context of a chapter 11 restructuring case under the US Bankruptcy laws, this procedure is comparable to a chapter 11 case where the debtor acts as a debtor-in-possession (DIP) and continues to manage the business during the bankruptcy proceeding (11U.S.C. $§ 1107$ ). However, unlike the DIP under the US system who assumes the role of the trustee, the debtor in a Protective Settlement Procedure is not explicitly given the same rights and duties of a trustee (officeholder), such as those listed in articles 58 and 59 of the KSA Bankruptcy Law in a Financial Restructuring Procedure.

The Financial Restructuring Procedure is a procedure under the supervision of the Financial Restructuring Officeholder, aiming to facilitate reaching an agreement between the debtor and its creditors for the financial restructuring of the debtor's activity [Bankruptcy Law 2018 (KSA), art. 1]. A key distinction of this procedure from the Protective Settlement Procedure is that the management of the business during bankruptcy will be under the Officeholder's supervision [Bankruptcy Law 2018 (KSA), art. 57]. The details and provisions governing the Financial Restructuring Procedure are laid out under chapter 4, articles 42-91 of the law [Bankruptcy Law 2018 (KSA)].

The liquidation procedure is a procedure under the management of the liquidation officeholder, aiming to account for creditors' claims, the sale of the bankruptcy assets and the distribution of the sale proceeds to the creditors [Bankruptcy Law 2018 (KSA), art. 1]. Chapter 5 of the KSA Bankruptcy Law covers this procedure in articles 92-126.

A small debtor is defined under Article 1 of the law as a debtor who meets the criteria adopted by the Bankruptcy Commission in coordination with the General Authority for Small and Medium Entities [Bankruptcy Law 2018 (KSA), art. 1]. The three Small Debtors Procedures (Protective Settlement, Financial Restructuring and Liquidation) are covered in Chapter 6 (articles 127-141), Chapter 7 (articles 142-159) and Chapter 8 (articles 160-166), respectively. The Small Debtors Procedures are similar to the main procedures in operation but tailored toward small debtors and shorter time-frames, with the aim to achieve the restructuring or liquidation within a reasonable timeframe, through simple, low-cost and efficient proceedings [Bankruptcy Law 2018 (KSA), art. 127, 142, 160].

The Administrative Liquidation Procedure as defined in Article 1 is a procedure under the management of the Bankruptcy Commission, aiming to sell the Bankruptcy Assets which sale proceeds are not expected to cover the expenses of the liquidation procedure or 
the Small Debtors' Liquidation Procedure [Bankruptcy Law 2018 (KSA), art. 1]. Chapter 9 of the KSA Bankruptcy Law covers this procedure under articles 167-181.

Other important chapters of the KSA Bankruptcy Law that are worth highlighting are Chapter 2, which establishes the Bankruptcy Commission and details its functions and responsibilities; Chapter 10, which covers the financing options available for debtors under the different bankruptcy procedures; and Chapter 12, which discusses creditor priority and debt ranking.

\section{Jurisdiction, oversight and standing}

This part explores certain preliminary matters that are essential in understanding the operation of a bankruptcy proceeding under the KSA bankruptcy law. Specifically, Section 3.1 discusses the jurisdiction of the commercial courts of the Kingdom over bankruptcy cases. Section 3.2 introduces the Bankruptcy Commission and its oversight role in bankruptcy. Section 3.3 of this part discusses parties of interest that have standing to participate in a bankruptcy case.

\subsection{Court jurisdiction}

Under Article 6 of the KSA Bankruptcy Law, jurisdiction over bankruptcy cases is granted in the commercial courts of the Kingdom (the court), where they are to issue the necessary judgements and decisions to implement the procedures under the law, oversee the law's implementation, hear all arising disputes and impose any related penalties or sanctions. In addition, the courts have been granted a clear subpoena power to ensure all necessary disclosures are obtained [Bankruptcy Law 2018 (KSA), art. 6]. Furthermore, the new bankruptcy law supersedes other laws and exclusively governs the liquidation of any person or entity unless their assets are sufficient to cover all their debts and they are not distressed under the law. Any voluntary dissolution or liquidation in violation of this requirement will impose personal liability on the member of the board of directors [Bankruptcy Law 2018 (KSA), art. 7].

\subsection{Bankruptcy commission}

Chapter 2 of the KSA Bankruptcy Law establishes the Bankruptcy Commission and defines its functions and responsibilities in articles 9-12. The Bankruptcy Commission is a financially and administratively independent body that is assigned many responsibilities in furtherance of the new bankruptcy law, including promulgating regulations for licensed trustees and inspecting and verifying compliance with the law [Bankruptcy Law 2018 (KSA), art. 9]. Similarly, in the context of the US bankruptcy system, the US Trustee Program (USTP) is an independent body that monitors compliance with the law and protects the integrity of the bankruptcy system by overseeing case administration and litigating to enforce the bankruptcy laws (11U.S.C. § 704).

\subsection{Parties with standing}

Before diving into the details of the different bankruptcy procedures under the KSA Bankruptcy Law, a brief discussion and definition is warranted of parties of interest that have standing to participate in the system.

Under the KSA Bankruptcy Law, key parties that have standing to participate in a bankruptcy proceeding include the debtor, the creditors, the owners, the officeholder and the Bankruptcy Commission. 
3.3.1 Debtor. In every bankruptcy proceeding, there is a debtor, where a debtor is defined as a person proven to be indebted, with "person" meaning both a natural or corporate personality. Under the definitions section of the law, debt is defined as a proven financial obligation owed by a debtor [Bankruptcy Law 2018 (KSA), art. 1].

3.3.2 Creditors. Every bankruptcy proceeding will have one or more creditor. A creditor is defined under the law as a person proven to be owed a debt payable by a debtor [Bankruptcy Law 2018 (KSA), art. 1]. In addition, the law limits creditors' participation under certain procedures (Financial Restructuring Procedure, Liquidation Procedure and Small Debtors Financial Restructuring Procedure) to creditors whose debt has been established prior to the commencement of the case, whether their claims are due, future or conditionally suspended or potential claims [Bankruptcy Law 2018 (KSA), art. 63, 126, 151].

3.3.3 Owners. An owner is defined as a person holding a quota or a share in the debtor's capital. However, under certain procedures (Protective Settlement, Small Debtors Protective Settlement), owners' participation to vote on a proposal is limited to cases where the proposal would affect the owners' rights [Bankruptcy Law 2018 (KSA), art. 1].

3.3.4 Officeholder. A bankruptcy officeholder is defined as whoever appointed by the court or an applicant to perform the tasks and duties entrusted to him/her in accordance with the type of procedure [Bankruptcy Law 2018 (KSA), art. 1]. An officeholder under the KSA Bankruptcy Law is akin to a trustee under the US bankruptcy laws, and their assigned duties and powers include verifying the soundness of the debtor's management and monitoring its financial operations, attending creditors meetings and performing the duties entrusted to him by the Court or the Regulations (11U.S.C. $\S 704$ ). In this paper, the terms officeholder and trustee are used interchangeably referring to the same party.

The Bankruptcy Commission is a key party assigned many responsibilities, including inspecting and verifying compliance with the law, and in the Administrative Liquidation Procedure; the Commission replaces the debtor in managing its activities and carrying out its duties pertaining to the administrative procedure [Bankruptcy Law 2018 (KSA), art. 9].

\section{Analysis of a bankruptcy case under the law}

Under a general framework of a typical bankruptcy case, key procedures and features of the KSA Bankruptcy Law are discussed from an operational perspective to a bankruptcy practitioner, a policy perspective and whether the general bankruptcy policies are advanced or hindered by such features and, where relevant, from a comparative perspective to that of US bankruptcy system. The framework adopted for the analysis is in the following structure: Scope of Protected Debtors; Commencement of a Case; Bankruptcy Assets and Revocable Transactions; Officeholder or Trustee's Role; Claim Moratorium; Debt Ranking and Priority; and Dischargeability of Debt. Each section in this part explores and evaluates the provisions of the law under the structure of this framework.

\subsection{Scope-who qualifies as a debtor?}

Under the KSA Bankruptcy Law, a debtor is eligible to file for several bankruptcy procedures if he falls under any of the following: If he/she is more likely to suffer financial difficulties leading to distress; if he is distressed, defined as a debtor who stopped paying a due debt on its due date; or if he is bankrupt, defined as a debtor whose debts have consumed all of its assets [Bankruptcy Law 2018 (KSA), art. 13, 42]. It must be noted that the law does not limit debtor's eligibility to being balance-sheet insolvent, rather as set in the first eligibility criteria, it allows a debtor the ability to file for bankruptcy protection before reaching such stage. Allowing the debtor early access to the protections of the law before its financial situation becomes irrecoverable, has the effect of increasing the chances 
of saving the bankrupt business and allowing it to continue operating profitably. Coupled with other provisions in the law such as allowing the debtor to manage its own business post-filing in some bankruptcy procedures, such rules would incentivize and encourage debtors who expect financial distress to file early for bankruptcy protection. Thus, enhancing the business's survival prospects to the benefit of all stakeholders. By enabling solvent debtors to commence insolvency proceedings, the law is giving debtors the ability to organize their financial position without being impaired by creditors' claims or loss of assets.

To understand the scope of the law and debtors eligibility, it must be understood who qualifies as a debtor under the law. A debtor is defined as a person proven to be indebted, with person meaning both a natural or corporate personality. Under the definitions section of the law, debt is defined as a proven financial obligation owed by a debtor. Furthermore, Article 4 of the law determines the scope of the bankruptcy laws protection by determining which debtors are protected by the law, which are as follows: A natural person practicing a commercial activity or a professional activity or any activity with an aim to generate profits in the Kingdom; commercial, professional and civil companies, regulated entities as well as other entities or establishments with an aim to realize profits, registered in the Kingdom; and non-Saudi investors, participating in activities in the Kingdom that fall under the aforementioned two prongs, extending only to the investor's assets located in the Kingdom [Bankruptcy Law 2018 (KSA), art. 4].

Considering the limited scope of eligible debtors under the law, the KSA Bankruptcy Law appears to be mostly business oriented as it clearly excludes individual consumer bankruptcies from the protection of the law. Contrasting the KSA bankruptcy regime to other modern bankruptcy regimes, specifically that of the USA, there is a lack of consumer bankruptcy under the KSA Bankruptcy Law. This appears to be a conscious policy decision made under the KSA Bankruptcy Law that will likely hinder certain debtors from contributing to economy by not having access to the bankruptcy system for their individual or consumer liabilities. Further investigation into the policy reasons behind this decision and whether it relates to debts and liabilities under the Kingdom's Shariah law is warranted; however, it is beyond the scope of this paper.

Finally, under the Financial Restructuring Procedure, filing for bankruptcy and commencing a case is not limited to the debtor. Article 42 of the KSA Bankruptcy Law extends the eligibility to begin a proceeding under this section to creditors and authorities in charge of regulated entities if the debtor meets the eligibility criteria discussed above [Bankruptcy Law 2018 (KSA), art. 42]. However, unlike the US bankruptcy system, the Kingdom's laws do not set out requirements that a certain number of creditors must join the filing before putting a debtor into an involuntary bankruptcy to protect from creditor abuse when only a small number of creditors seek to put the debtor into bankruptcy [Bankruptcy Law 2018 (KSA), art. 47]. Nonetheless, the KSA Bankruptcy Law seems to provide protection against creditor abuse by requiring the court's approval of the debtor's eligibility at the filing stage.

\subsection{Commencement of a case}

Assuming a debtor meets the eligibility requirements discussed above, the commencement of a case requires a filing with the court of an application for the specific bankruptcy procedure. The determination of the specific procedure to file under depends on the financial status of the debtor, the party seeking to commence the case, the preferred management of the business and satisfaction of the filing requirements for the desired procedure. Each procedure has a different set of requirements for filing and commencement of a case that will 
be discussed in detail below. The discussion will be limited to the main four procedures under the KSA Bankruptcy Law, excluding the three small debtors' procedures as procedurally they mostly mirror the main procedures with minor differences to accommodate for their purpose to serve small debtors' bankruptcies.

4.2.1 Commencement of a protective settlement procedure. Under the KSA Bankruptcy Law, a case for a Protective Settlement Procedure commences upon the court's approval of the debtor's filed application [Bankruptcy Law 2018 (KSA), art. 15]. The requirement for judicial determination that the debtor meets the filing requirements before a case is commenced creates the burden of convincing the court that a debtor is eligible to the protections of the law at the filing stage. In contrast, under the US Chapter 11 Bankruptcy proceeding, a proceeding is commenced automatically upon filing, giving debtors access to certain protections of the law such as the automatic stay without judicial intervention (11U. S.C. $\S 301)$.

Only the debtor may file an application for the commencement of the Protective Settlement Procedure [Bankruptcy Law 2018 (KSA), art. 13]. The debtor must file the application together with the proposal, which must include background information on the financial position of the debtor, the effects of the economic situation thereon and classification of creditors into categories [Bankruptcy Law 2018 (KSA), art. 14]. In contrast to the US system where the plan is developed at a later stage (11U.S.C. $§ 1121$ ), the requirement that the proposal and creditor classification be ready at the filing stage adds an additional burden on the debtor before he/she is given access to the protections of the law. Creating such burdens at the filing stage could have an undesired effect of deterring certain debtors from using the system at an early stage and losing the benefits of early filing previously discussed.

A court will approve the application for the commencement of the procedure if the debtor's activities are likely to continue, and the creditors' claims will be settled within a reasonable timeframe; the debtor is distressed, bankrupt or likely to suffer financial difficulties leading to distress; (3) the debtor submits the information and documents required; the debtor has classified with due care the creditors into categories in a fair manner [Bankruptcy Law 2018 (KSA), art. 15].

4.2.2 Commencement of a financial restructuring procedure. The Financial Restructuring Procedure similarly requires court determination to commence the proceeding [Bankruptcy Law 2018 (KSA), art. 47]. However, an application for a Financial Restructuring Procedure can be filed by the debtor, the creditor or the competent authority assuming the debtor meets the eligibility requirements [Bankruptcy Law 2018 (KSA), art. 42]. The debtor is entitled to object to any filing made by a person other than the debtor if any of the following grounds apply: the conditions for commencement of the procedure are not applicable; the debt is disputed; or the creditor aims to abuse the procedure [Bankruptcy Law 2018 (KSA), art. 44].

It is worth noting that the law does not set minimum requirements for the number of creditors or amount of debt to be eligible to put the debtor in bankruptcy. This diverges from the US bankruptcy system where the law sets certain requirements to limit abuse by a small number of creditors at the expense of the majority of creditors and the debtor (11U.S.C. $\S 303)$. However, this policy goal in curbing abuse is somewhat achieved under the KSA Bankruptcy Law by requiring court approval of the application and allowing the debtor to object in involuntary cases.

Unlike the Protective Settlement Procedure, the proposal and creditors classification are not required at the filing stage [Bankruptcy Law 2018 (KSA), art. 75]. The development of the proposal at a later stage in the proceeding is in alignment with a chapter 11 case under 
the US bankruptcy system, which has the benefit of lessening the burdens on debtors to seek bankruptcy early on in their financial distress, increasing the prospects of successfully saving the business.

A court will approve the application for the commencement of the procedure if the debtor's activities are likely to continue, and the creditors' claims will be settled within a reasonable timeframe; the debtor is distressed, bankrupt or likely to suffer financial difficulties leading to distress; the debtor submits the information and documents required [Bankruptcy Law 2018 (KSA), art. 47].

4.2.3 Commencement of a liquidation procedure. A liquidation procedure may be commenced only if the debtor is bankrupt or distressed, and the application to commence the procedure may be filed by the debtor, the creditor or the competent authority [Bankruptcy Law 2018 (KSA), art. 92]. If the application is filed by a creditor or a group of creditors, the following conditions must be met: the debt must be due and its amount, cause and related security interest must be identified; the amount of debt must not be less than the amount determined by the Bankruptcy Commission; the debt must be either due pursuant to a writ of execution or an ordinary document, and the creditor must prove that payment has been requested 28 days prior to the date of the application. Furthermore, the debtor must have not disputed the debt prior to the date of submission of the creditor's request [Bankruptcy Law 2018 (KSA), art. 93].

The imposition of the aforementioned eligibility requirements on creditors to be able to put the debtor into a liquidation bankruptcy proceeding prevents abuse by creditors of the system to the benefit of both the debtor and the majority of creditors. As creditors whose debts do not meet the required amount or status set out in the law for eligibility to commence a liquidation proceeding, will not be able to forcefully put the debtor into bankruptcy to the detriment of the majority of stakeholders.

Additionally, the law provides the debtor with the right to object to a creditor's application, and elect to commence a Protective Settlement or Financial Restructuring Procedure instead, as applicable [Bankruptcy Law 2018 (KSA), art. 95].

Upon filing of an application, and assuming the aforementioned requirements are satisfied, the court will approve the application and commence the proceeding if the debtor is distressed or bankrupt; the court finds that the continuation of the debtor's activities is not possible, and the debtor's assets are insufficient to meet liquidation expenses; and the applicant has submitted the required information and documents [Bankruptcy Law 2018 (KSA), art. 99].

4.2.4 Commencement of an administrative liquidation procedure. The debtor or the competent authority may apply to the court for the commencement of the Administrative Liquidation Procedure. The debtor must be distress or bankrupt, and its assets are insufficient to cover the Liquidation Procedure expenses [Bankruptcy Law 2018 (KSA), art. 168]. If the competent authority submits the commencement of procedure application, the debtor may object and elect any other applicable procedure [Bankruptcy Law 2018 (KSA), art. 168].

Upon filing of an application, and assuming the aforementioned requirements are satisfied, the court will approve the application and commence the proceeding if the debtor is distressed or bankrupt; it is more likely that the debtor would not maintain its activities and its sale proceeds are insufficient to cover the expenses of a Liquidation Procedure; and (3) the applicant submitted the required information and documents [Bankruptcy Law 2018 (KSA), art. 170]. 
This section introduces the concept of the bankruptcy assets that come into existence in bankruptcy, as well as exploring the court's power to recover certain assets wrongfully disposed of by the debtor prior to entering into bankruptcy.

4.3.1 Bankruptcy assets. An important concept in bankruptcy is the bankruptcy assets (or as it is known under the US bankruptcy law, Property of the Estate), which comes into existence upon the commencement of a bankruptcy case, and is distinct from Property of the Debtor. Typically, it includes all the debtor's property rights and assets at the commencement of the case, except for certain exempted property. The distinction between the bankruptcy assets and what remains as the debtor's property separates property that will be subject to the bankruptcy protections and distribution, and property that will be outside the scope of bankruptcy.

Under the KSA Bankruptcy Law, the bankruptcy assets are the debtor's assets on the date of the commencement of any of the bankruptcy procedures or during the process of any of the bankruptcy procedures, which include movable and immovable assets, intellectual property rights, entitlements due from third parties whether due or not and any rights attached thereto and other assets which may have current or future financial value [Bankruptcy Law 2018 (KSA), art. 1]. By casting a wide scope for what constitute bankruptcy assets, the law is in alignment with modern bankruptcy codes, such as that of the USA under what constitutes Property of the Estate, and aims to protect creditors rights by encompassing all financially valuable assets (11U.S.C. § 541). However, limited exemptions exist to debtors who are a natural person in a Liquidation Procedure for assets that are reasonably required to provide necessary financial support and maintain a reasonable standard of living (Bankruptcy Law 2018 (KSA), art. 66, 102).

Identifying the bankruptcy assets is an essential step early in any bankruptcy proceeding, as it will determine what assets are subject to the moratorium, officeholder's responsibilities and bankruptcy distribution. Each of these features will be discussed in further detail in the relevant sections below.

4.3.2 Revocable transactions. A closely related concept is the treatment of debtors assets disposed of within a set period prior to the beginning of the bankruptcy proceeding. The discussion in this section covers what is typically referred to as the court's avoidance powers or revocable transactions as it is called under the KSA Bankruptcy Law. To preserve the bankruptcy assets and prevent debtors abuse of the system, the law grants the court the power to revoke certain transactions and recover the assets to be included in the bankruptcy assets. In the context of the US Bankruptcy law, a similar approach is taken in treating any assets recovered under the avoidance powers as part of the Property of the Bankruptcy Estate (11U.S.C. $§ \S 547,548)$.

Under the KSA Bankruptcy Law, any interested party has the right to object before the court against certain actions taken by the debtor in disposing of assets within 12 months preceding the commencement of the proceeding if the transaction was with an unrelated party, and within 24 months if the transaction was with a related party [Bankruptcy Law 2018 (KSA), art. 210]. The court will rule by nullifying the debtor's disposal of assets and its consequences, unless the disposal was in the interest of the debtor who was not distressed or bankrupt at the time of making such disposal [Bankruptcy Law 2018 (KSA), art. 211].

The following acts by the debtor are within the scope of the court's revocation power: assigning any of its assets, rights or security interests; executing transactions without consideration or for a consideration that is below its fair value; executing transactions involving the settlement of debts prior to their maturity dates or the unfair settlement of 
debts; providing security for debts prior to them being recorded as liabilities; and discharging its debtor wholly or partially from its due debt [Bankruptcy Law 2018 (KSA), art. 210].

\subsection{Bankruptcy officeholder (trustee)}

Another important aspect of bankruptcy that occurs after the commencement of a proceeding, is the appointment of a Bankruptcy Officeholder or Trustee. The Trustee is entrusted with various duties and granted certain rights to ensure an orderly progress of the proceeding, and to maximize the value of the bankruptcy assets for the benefit of all creditors and safeguard their interests.

4.4.1 Protective settlement procedure trustee. Under the KSA Bankruptcy Law, the presence of the trustee is prominent in the Financial Restructuring Procedure and the Liquidation Procedure. However, under the Protective Settlement Procedure, the role of the trustee is in practice assumed by the debtor who continues to manage the business during the proceeding [Bankruptcy Law 2018 (KSA), art. 1]. In the context of a chapter 11 case under the US bankruptcy system, the debtor in a Protective Settlement Procedure is akin to a DIP, who assumes the role of the trustee and continues managing the business during the bankruptcy case (11U.S.C. § 1107). However, while the debtor continues management of the business under the Protective Settlement Procedure, there is a lack of provisions under the law that expressly grant the debtor rights similar to those of the trustee in a Financial Restructuring Procedure, which will be discussed below [Bankruptcy Law 2018 (KSA), art. 58, 59]. From a policy perspective, this is a valuable feature in a bankruptcy system, as it increases the prospects of debtors in financial strain to file early for bankruptcy and restructure their debts if they are provided the opportunity to continue managing their business during the proceeding. In the context of Saudi Arabia's aim to attract foreign investment, the presence of the DIP feature is of increased importance as it would appeal to sophisticated foreign investors and businesses who would rather maintain the management of their businesses if they are in bankruptcy than outsource it to local bankruptcy officeholders.

4.4.2 Financial restructuring procedure trustee. In a Financial Restructuring Procedure, the court appoints the trustee, while the party applying for the commencement of the proceeding may suggest to the court a named trustee [Bankruptcy Law 2018 (KSA), art. 50]. The trustee must exercise the necessary duty of care to safeguard the interests of creditors, and must be trustworthy and honest in carrying its duties and responsibilities [Bankruptcy Law 2018 (KSA), art. 50]. During the proceeding, the trustee is granted the following duties and powers: verifying the soundness of the debtor's management of its activities and monitoring its financial operations; attending litigation hearings, creditors meetings and meetings of other matters related to the proceeding; carrying out any ancillary or incidental actions to his/her original functions and powers; performing the duties entrusted to him/her by the court; and performing any other duties under the regulations [Bankruptcy Law 2018 (KSA), art. 58].

Additionally, the trustee is granted the following rights and protections to further his/her ability to perform its role: the right to access all the debtors' information or documents held by the court, as well as receiving from the debtor any additional relevant information, including all amounts owed by the debtor to third parties or contracts that are not disclosed to the court; the right to obtain and maintain all information and documents relating to the bankruptcy assets; may request that a creditor submit additional information in support of its claim; the right to obtain any information about the debtor's activities or bankruptcy 
assets from public and private entities to the extent necessary to enable him/her to perform his/her duties [Bankruptcy Law 2018 (KSA), art. 59].

4.4.3 Liquidation procedure trustee. In the context of a Liquidation Procedure under the KSA Bankruptcy Law, the trustee's role is to liquidate the bankruptcy assets, verify creditors' claims and maximize the distribution to creditors through selling the assets at the best price possible [Bankruptcy Law 2018 (KSA), art. 102-104].

The trustee's role in the management of the business differs from that under the restructuring procedures discussed above. In a Liquidation Procedure, upon the commencement of the proceeding and appointment of a trustee, the debtor immediately ceases to manage its activities and the trustee replaces the debtor in the management of its activities [Bankruptcy Law 2018 (KSA), art. 100]. Any action taken by the debtor over any bankruptcy assets after the appointment of the trustee is considered null and void, and the court may order the recovery of said assets [Bankruptcy Law 2018 (KSA), art. 100].

In addition, the trustee under a Liquidation Procedure is granted the same rights of the Financial Restructuring Trustee discussed above [Bankruptcy Law 2018 (KSA), art. 126].

\subsection{Claim moratorium}

One of the most fundamental protections provided by bankruptcy is what is referred to as the moratorium or the stay. The moratorium provides protection to the debtor, the debtor's assets and the bankruptcy's assets from any act of collection by enjoining creditors and others from pursuing these assets once the moratorium is in place. This effectively provides the debtor with the most needed relief from financial pressures in the early stages of bankruptcy, granting the debtor the time to be able to restructure its financial position and negotiate the proposal in a restructuring case. While in a liquidation case, it ensures that all the assets are distributed to all creditors in an orderly and fair manner, preventing individual creditors from pursuing the assets to satisfy their own debts at the expense of the majority of the creditors. This effectively eliminates a disorderly race to collection among creditors that would arise in the absence of a moratorium.

4.5.1 Triggering of the moratorium, duration and termination. In the context of the US bankruptcy system, the moratorium is referred to as the automatic stay. That is because it is automatically triggered immediately upon the filing of a case, providing the aforementioned benefits while the stay is in place (11U.S.C. § 362). Under the KSA Bankruptcy Law, whether the moratorium is automatically triggered depends on the specific procedure filed. In both the Financial Restructuring Procedure and the Liquidation Procedure, the filing of the application or the commencement of the procedure automatically triggers a Claim Moratorium [Bankruptcy Law 2018 (KSA), art. 46, 97]. While for the Protective Settlement Procedure, the mere filing of the bankruptcy proceeding will not automatically result in a Claim Moratorium, which must be requested by the debtor and requires a court order to create the moratorium [Bankruptcy Law 2018 (KSA), art. 17]. Furthermore, the moratorium in a Protective Settlement Procedure if ordered by the court will be from the date of ordering the commencement of the procedure, and not the filing of the application [Bankruptcy Law 2018 (KSA), art. 18]. From a policy perspective, the lack of an automatic stay and the delay in starting it would detract from the aforementioned benefits that an automatic stay provides.

In a Protective Settlement Procedure, the debtor must request from the court to order a Moratorium, otherwise, it will not be triggered automatically [Bankruptcy Law 2018 (KSA), art. 17]. The maximum period possible for a moratorium granted by the court will not exceed 180 days, with an initial period of 90 days, followed by 30-day extensions, starting from the day of commencement of the procedure [Bankruptcy Law 2018 (KSA), art. 18]. The moratorium expires upon the lapse of its stated period, or the earlier of the ratification of the 
proposal or the termination of the procedure. Furthermore, the debtor must notify the creditors of the court's decision ordering the Claim Moratorium immediately upon issuance [Bankruptcy Law 2018 (KSA), art. 19].

In a Financial Restructuring Procedure, the filing of the application automatically results in a Claim Moratorium for 180 days, which may be extended by the court for another 180 days [Bankruptcy Law 2018 (KSA), art. 46, 91]. The moratorium terminates by the lapse of its period, or before that if the application is rejected, the proposal is ratified or the procedure is terminated [Bankruptcy Law 2018 (KSA), art. 46, 91].

However, in a Liquidation Procedure, the registration of an application for the commencement of the Liquidation Procedure or the commencement of the procedure automatically creates a moratorium (Bankruptcy Law 2018 (KSA), art. 97). The moratorium lasts until the date of issuance of a court judgement rejecting the application or a judgement terminating the procedure [Bankruptcy Law 2018 (KSA), art. 97].

4.5.2 Effects of a moratorium under the restructuring procedures. A Claim Moratorium operates in the same manner under both the Protective Settlement Procedure, and the Financial Restructuring Procedure, and has a similar effect [Bankruptcy Law 2018 (KSA), art. 20, 21, 91]. During the period of the moratorium, any act in violation of the moratorium shall be null and void, and the court may order the recovery of assets disposed of in violation of the moratorium or take other appropriate action, taking into account the rights of third parties acting in good faith [Bankruptcy Law 2018 (KSA), art. 20]. Acts that are not permitted to be taken or completed during a moratorium include any acts against the debtor or its assets, any enforcement procedure over bankruptcy assets as security interest, any act against the personal guarantor or the in-kind guarantor of the debtor's debt [Bankruptcy Law 2018 (KSA), art. 20].

While exceptions apply for relief from the moratorium with the consent of the court for acts against secured assets of the debtor or guarantors [Bankruptcy Law 2018 (KSA), art. 21]. The court shall grant relief if either the enforcement does not affect the ability of the debtor to continue its activity, or does not affect the ability of the debtor to obtain consent for the proposal; and the rejection of such application could cause serious damages to the secured creditor where the debtor will not be able to compensate for, and where such damage outweighs the damage that would affect the debtor and other creditors [Bankruptcy Law 2018 (KSA), art. 21]. These exemptions from the moratorium are similar to the requirements for relief from the automatic stay under the US Bankruptcy system where relief is granted if the asset is not necessary for reorganization, or where the debtor cannot provide adequate protection to the creditor (11U.S.C. § 362).

In the context of the application of the moratorium to secured creditors, the underlying policy aims to balance the contracted rights of the secured creditor to its collateral, and the possibilities of having a successful restructuring that will benefit all. In that sense, the secured party will be allowed to collect its collateral if said asset is not necessary for a successful reorganization, or if it cannot be guaranteed compensation for its losses because of giving away its rights to the collateral for the benefit of an organization.

4.5.3 Effects of a moratorium under the liquidation procedure. During the period of the moratorium, any act in violation of the moratorium shall be null and void, and the court may order the recovery of assets disposed of in violation of the moratorium or take other appropriate action, taking into account the rights of third parties acting in good faith [Bankruptcy Law 2018 (KSA), art. 97].

The court may authorize upon the request of a secured creditor, taking enforcement actions against a bankruptcy assets securing the debtor's debt [Bankruptcy Law 2018 (KSA), art. 97]. The difference in treatment of secured creditors in a Liquidation Procedure is 
based on the fact that no restructuring or reorganization is sought out of the procedure, and the only right at play is that of the secured creditor to its collateral.

Furthermore, the court will consider the application of creditors the majority of whose funds are in the possession of the debtors [Bankruptcy Law 2018 (KSA), art. 97]. In addition, the court may, at the request of an interested party, suspend the moratorium for specific claims, which were subject to a certain action prior to the moratorium, if the court finds that such action is in the interest of the debtor and the majority of creditors [Bankruptcy Law 2018 (KSA), art. 97]. This divergence in the effect of a moratorium from that in the restructuring procedures is because of the different policy goals in play under each procedure. In a Liquidation Procedure, there is no concern to any likelihood of future success of a business. Furthermore, leaving the decision to determine the lifting of the moratorium in such situation with the court is in alignment with the equitable distribution policy of bankruptcy which will require the court to evaluate cases on a case-by-case basis.

\subsection{Debt ranking and creditor priority}

A creditor's or claim holder's ability to recover in bankruptcy is dependent on the claim's ranking under the priority scheme set by the law. Underlying the debt ranking and priority scheme, two major policies are at play: fairness among creditors, and ensuring the success of a single collective bankruptcy proceeding for the benefit of all creditors. The first policy goal is evident in the order of priority set among creditors' claims, where fairness among creditors requires that certain types of claims, such as secured debt, are given higher priority than others. However, the second policy goal is expressed in giving the administrative expenses of the bankruptcy proceeding first priority, as without such an incentive to officeholders and other bankruptcy professionals, the success of the whole proceeding would face uncertainty for lack of willing personnel to take on the responsibility without guaranteed payment.

Under the KSA Bankruptcy Law, the priority scheme is relevant and applicable only under the Liquidation Procedures, because under the restructuring procedures with no discharge of liabilities, the ranking is irrelevant as all creditors would expect their claims included to the fullest in the restructuring plan [Bankruptcy Law 2018 (KSA), art. 195, 196]. From a policy perspective, this could have a negative effect on the negotiation and approval process of the restructuring proposal. However, the balance of power is restored by the fact that lower ranked creditors would risk the case be transformed into a Liquidation Procedure if a plan is not approved.

Under the KSA Bankruptcy Law, the first priority is given to the fees and expenses of the Bankruptcy Officeholder and experts, and the expenses of the Bankruptcy Assets in a Liquidation Procedure [Bankruptcy Law 2018 (KSA), art. 195]. This is in alignment with the order of priority under the US Bankruptcy coder, where administrative expenses are given first priority (11U.S.C. $\S \S 726,507)$. Following the administrative expenses discussed above, debts are ranked in the following order by seniority: debts secured by real security interests; secured financing and other security interests; debtor's employees wage entitlements of 30 days; family expenses established pursuant to a statutory provision or court order; expenses necessary for the continuation of the debtor's operations during the procedure; preceding wages to debtor's employees; unsecured debts; and (8) fees, subscriptions, taxes and unsecured government entitlements [Bankruptcy Law 2018 (KSA), art. 196].

Distributions are made following the ranking order to all creditors of an equal rank before moving to the next rank, and if the assets are insufficient to satisfy all the claims within a rank, the distributions shall be paid on a pari-passu basis between the creditors of that rank [Bankruptcy Law 2018 (KSA), art. 198]. 
For over-secured creditors, if the proceeds of the sale of the collateral exceed the secured debt, the excess of the proceeds becomes part of the bankruptcy assets [Bankruptcy Law 2018 (KSA), art. 197]. However, if the creditor was under-secured, any outstanding liabilities post the sale become unsecured debt [Bankruptcy Law 2018 (KSA), art. 197]. Compared to the US Bankruptcy system, the process here is more straightforward with the absence of the Cushion Theory and its diverse interpretations and analysis [1].

\subsection{Dischargeability of debt}

As discussed in the Modern Bankruptcy Law section, a fundamental goal of modern bankruptcy systems is the dischargeability of debt and the fresh-start concept, which provide debtors and businesses the opportunity to continue contributing to the economy unhindered by past failures and overhanging liabilities by relieving the honest debtor from the weight of indebtedness. The absence of a discharge of debts and liabilities in bankruptcy will deter businesses and risk taking with such risk of overhanging liabilities continuing to haunt them.

Under the KSA Bankruptcy Law, there is a clear absence of this policy goal [Bankruptcy Law 2018 (KSA), art. 5]. Under the restructuring procedures (Protective Settlement, Financial Restructuring), there is no discharge of debts with the presumption that the bankruptcy assets will satisfy the liabilities, or the debtor should go through an Administrative Liquidation Procedure [Bankruptcy Law 2018 (KSA), art. 123, 125]. From a policy perspective, this alters the balance of powers and rights in the negotiation and voting phase of a proposal as the creditors generally lack the incentive to release the debtor from any liabilities. Although in limited cases where certain creditors are dependent on the debtor's survival, such as trade creditors that have the debtor as their primary business partner, the incentive might exist for these creditors to discharge some of their debt if it will ensure the success of the debtor's restructuring. This is clear divergence from the US bankruptcy law where discharge of debt is an essential part of the system, and any debts not included in the restructuring plan or liquidation process are discharged, granting the debtor a fresh-start and ability to recontribute to the economy [11U.S.C. $\S \S 727,1141]$.

In an Administrative Liquidation Procedure, the KSA Bankruptcy Law specifically states that corporate entity debtors are not discharged from remaining liabilities unless it is pursuant to a general discharge from creditors [Bankruptcy Law 2018 (KSA), art. 181]. However, how this would operate in practice is unclear as a liquidated entity should cease to exist post-dissolution and by default ought to be discharged if it is of limited liability [Bankruptcy Law 2018 (KSA), art. 122]. However, in a Liquidation Procedure, the corporate debtor would be dissolved, and if it completed the procedure without converting to an Administrative Liquidation Procedure, the presumption is that all the debts have been satisfied.

As for natural person debtors, the law specifically does not grant a discharge without a release from creditors in a Liquidation Procedure, and are considered bankrupt in respect of the rights of remaining creditors for a period of 24 months from the termination of the procedure [Bankruptcy Law 2018 (KSA), art. 125]. While in an Administrative Liquidation Procedure, the natural person debtor who was discharged from a due and remaining debt will also be deemed bankrupt in respect of the rights of remaining creditors for a period of 24 months from the termination of the Administrative Liquidation Procedure [Bankruptcy Law 2018 (KSA), art. 181]. Such creditors shall not be entitled to request the court to initiate any bankruptcy procedures during that period [Bankruptcy Law 2018 (KSA), art. 181]. 


\section{Conclusion}

The paper provided a survey of the KSA Bankruptcy Law, with a particular focus on specific features and provisions of the law that are most relevant to a bankruptcy practitioner representing debtors or creditors under any of the bankruptcy procedures available under the law. Furthermore, the law was analyzed from a policy perspective under both the general policies of a modern bankruptcy law, and the specific goals expressed in the KSA Bankruptcy Law. In analyzing the effectiveness of the law in meeting such policy objectives, the approach taken followed the operation and mechanism in which the law operates under a typical bankruptcy case by assessing the effectiveness of the specific features and provisions of the law in advancing or hindering these policy goals. In addition, the discussion in some parts compares the operation of the KSA Bankruptcy Law to that of the US Bankruptcy Law as an established and reputable bankruptcy regime.

Overall, the KSA Bankruptcy Law is a major accomplishment and advancement to the Kingdom's insolvency regime. The law consolidated and codified the laws governing bankruptcy under the Kingdom's prior regime, and followed the structure of a modern bankruptcy regime. In doing so, several of the law's policies and objectives have been fulfilled by providing an effective, predictable and reliable bankruptcy system. The effect of such system should help in achieving the Kingdom's goals in creating a business-friendly environment and attracting investment, ultimately benefiting the Saudi economy. Furthermore, as can be seen throughout analyses of the operational aspects of the law in the paper, the law generally operates in alignment with modern bankruptcy systems, specifically that of the USA.

The KSA Bankruptcy Law successfully creates several incentives to many parties affected by it to use its protections, and ultimately achieve the sought benefits of a successful bankruptcy case under a modern bankruptcy regime. Additionally, the law's orientation and focus appear to serve a larger constituency and do not limit the protections to a limited set of beneficiaries, by striking a balance in the rights and protections provided to the different key parties affected by it. As a result, this should further advance the objectives and beneficial outcomes it seeks to attain, and increase the likelihood of successful bankruptcies.

Nonetheless, there remain certain areas in which the law diverges from its comparable peer, that of the USA, and fails to achieve some of the general policies of modern bankruptcy regimes. In specific, the most prominent absentee under the KSA Bankruptcy Law and its stated objectives is that of Consumer Bankruptcy protections. As discussed in the paper, the new law is focused on business bankruptcy and does not extend to consumer bankruptcies. Introducing consumer bankruptcy to the Kingdom's bankruptcy regime should advance certain objectives of the law, specifically, benefiting the Kingdom's economy by relieving individual debtors from overhanging personal and consumer liabilities and allowing them the opportunity to contribute in the economy. Another absentee under the law is the dischargeability of debt and the fresh-start concept, which is a corner stone to any modern bankruptcy regime. However, the exclusion of both these protections may be rooted in the creditor-debtor contractual relationships under Shariah Law in the Kingdom, which is beyond the scope of this paper, but worthy of investigation because of the impact it has on the effectiveness of the law in its current state to achieve the goals of modern bankruptcy regimes. 


\section{Note}

1. The simplicity of the structure and treatment under the KSA Bankruptcy Law is probably because of the fact that interest is inapplicable under Islamic Finance and Saudi Law, which is beyond the scope of this paper.

\section{References}

Baird, D. G. (1983). "Notice filing and the problem of ostensible ownership", Journal of legal studies, Vol. 12, pp. 53-84.

Boude, R. (1984), "Cram down and chapter 11 of the bankruptcy code: the settlement imperative", The Business Lawyer, Vol. 39, pp. 441-454.

Brown, D.T. (1989), "Claimholder incentive conflicts in reorganization: the role of bankruptcy law", Review of Financial Studies, Vol. 2 No. 1, pp. 109-123.

George, S.K. (2018), "Bankrupting financial stress: New bankruptcy law of Saudi Arabia", Court Uncourt, Vol. 5 No. 7 , p. 36.

International Monetary Fund (1999), General Objectives and Features of Insolvency Procedures, International Monetary Fund (IMF), Washington, DC.

Jackson, T.H. (1985), "The fresh-start policy in bankruptcy law”, Harvard Law Review, Vol. 98 No. 7, pp. 1395-1396.

Tabb, C.J. (1995), "The history of bankruptcy laws in the United States", American Bankruptcy Institute Law Review, Vol. 3, pp. 5-7.

Warren, E. (1987), "Bankruptcy policy", The University of Chicago Law Review, Vol. 54 No. 3.

\section{Corresponding author}

Fahad Alarifi can be contacted at: alarifi.fahad@gmail.com

For instructions on how to order reprints of this article, please visit our website: 